\title{
JDP1 (DNAJC12/Hsp40) expression in breast cancer and its association with estrogen receptor status
}

\author{
SIMONE APARECIDA DE BESSA ${ }^{1}$, SIBELI SALAORNI ${ }^{1}$, DIOGO F.C. PATRÃO ${ }^{2}$, \\ MÁRIO MOURÃO NETO ${ }^{2}$, MARIA MITZI BRENTANI ${ }^{1}$ and MARIA APARECIDA NAGAI ${ }^{1}$ \\ ${ }^{1}$ Departamento de Radiologia, Disciplina de Oncologia da Faculdade de Medicina da Universidade de São Paulo, \\ Av. Dr. Arnaldo 455, $4^{\circ}$ andar, sala 4112, 01246-903; ${ }^{2}$ Hospital do Câncer A.C. Camargo, \\ Rua Professor Antonio Prudente 211, 01509-900, São Paulo, Brazil
}

Received August 2, 2005; Accepted September 20, 2005

\begin{abstract}
The members of the DnaJ/Hsp40 proteins are highly conserved through evolution, expressed in several tissues and act as co-chaperone regulating protein folding, transport, translational initiation and gene expression. Recently, using cDNA microarray we identified differences in the expression of the JDP1 (DNAJC12) gene, a member of the DnaJ/Hsp40 family, between ER-positive and ER-negative breast tumours. In this study, using quantitative real-time PCR (qPCR) we evaluated the expression pattern of the JDP1 gene in a series of 72 primary breast tumours and investigated the effects of $17 ß$-estradiol on the expression of the JDP1 in MCF-7 breast cancer cells. Three patterns of JDP1 mRNA expression were identified in the primary breast tumours analysed: normal expression was found in $14 \%$ of the cases, under-expression in $50 \%$, and over-expression in $36 \%$ of the cases. High levels of JDP1 mRNA expression were significantly associated with estrogen receptor-positive status $(\mathrm{p}=0.02)$. No relationship was found between JDP1 mRNA expression and any other clinicopathological characteristics of the patients. Sequence analysis of the promoter region of the $J D P 1$ gene revealed the presence of potential estrogen response elements (EREs), suggesting it to be under the control of estrogen action. We also assessed the effects of $17 ß$-estradiol $(10 \mathrm{nM})$ on JDP1 mRNA expression in MCF-7 breast cancer cells. The JDPI transcripts were found to be up-regulated in a time-dependent fashion in MCF-7 cells exposed to 17ß-estradiol treatment. Here we show for the first time that JDPl is a estrogen target gene and that its expression might be used as a marker of the ER transactivation activity and may have a predictive value for response to hormonal therapy.
\end{abstract}

Correspondence to: Dr Maria Aparecida Nagai, Disciplina de Oncologia, Departamento de Radiologia da Faculdade de Medicina da Universidade de São Paulo, Av. Dr. Arnaldo 455, $4^{\circ}$ andar, CEP 01246-903, São Paulo, Brazil

E-mail: nagai@usp.br

Key words: breast cancer, gene expression, Hsp40, JDP1 (DNAJC12), estrogen receptor, heat shock protein

\section{Introduction}

Lifetime exposure to estrogens is considered one of the main risk factors for breast cancer development $(1,2)$. Most of the biological effects of the estrogens are mediated by the estrogen receptors, ER $\alpha$ and $E R ß$, members of the steroid hormone receptor superfamily, which are ligand induced transcription factors $(3,4)$. Similar to other members of the steroid hormone receptor superfamily, ER forms large heterocomplexes with members of the heat shock proteins (Hsp90, Hsp70) and immunophilins (5). In the classic mechanism of estrogen action, the hormone binding to the ER leads to Hsp90 dissociation resulting in an estrogen-ER complex that directly interacts with estrogen response elements (EREs) in the promoter region of estrogen regulated genes $(3,4)$. The heterocomplex formed between the ER and Hsp90, Hsp70 and other co-chaperone proteins is important for the maintenance of the molecular conformation of the receptor and is required for an appropriate and efficient hormone binding to the receptor $(6,7)$.

Using cDNA microarray analysis we found a linear correlation between the expression of the DNAJC12 gene (also named JDP1; J domain containing protein 1) and the presence of estrogen receptor in breast tumours (8). The JDPI gene is located at chromosome 10q22.1 and encodes for the $\mathrm{J}$ domain containing protein 1 , a member of the smallmolecular-weight heat shock proteins (DnaJ/Hsp40) family, which has essential co-chaperone activity with other heat shock proteins (9). The members of the large family of DnaJ/ Hsp40 proteins are evolutively conserved and characterized by the presence of one or more J-domains in their N-terminal region $(10,11)$. The $\mathrm{J}$ domain, composed by three coiled coil helices spanning approximately 70 amino acids with the exposure of a tripeptide histidine-proline-aspartate (HPD) is important for the Hsp40-Hsp70 interaction and ATPase activity stimulation (12-14). There is also evidence that eukaryotic DnaJ homologue can interact physically and functionally with the major cytoplasmatic molecular chaperone Hsp90 $(15,16)$. In addition, in yeast, Ydj1/Hsp40 mutants displayed high basal levels of ER activity in the absence of estrogen suggesting that Ydj1/Hsp40 is important for the receptor regulation by the Hsp90 folding pathway (17). 
In the present study, in order to better understand the possible role played by the JDP 1 in breast cancer, we investigated the expression levels of the JDPl transcripts in a series of primary breast tumours using quantitative realtime PCR (qPCR). Additionally, we examined the potential promoter region of the $J D P 1$ gene for the presence of ERE binding sites and investigated the effects of 17ß-estradiol on the expression of the JDP1 transcripts in MCF-7 breast cancer cells.

\section{Materials and methods}

Samples. Seventy-two primary breast tumour samples and 20 adjacent normal tissues were obtained from 72 breast cancer patients at Hospital do Câncer, A.C. Camargo, São Paulo, Brazil. The age of the patients at the time of operation ranged from 23 to 93 years (median 54 years). Tumour samples were dissected to remove residual normal tissue before freezing and storage in liquid nitrogen. The largest diameter of the tumours was recorded. The number of lymph node metastases was determined by microscopic examination of an average of 24 lymph nodes per patient. Tumour metastasis at lymph nodes was detected in 47 patients. All the cases were submitted to a histopathological review of tumour slides in order to confirm diagnosis. All tumours were classified according to the WHO Histological Typing of Breast Tumours (WHO, 1982). The tumours studied were infiltrating ductal carcinomas. The clinical stage of the patients was determined according to the UICC TNM (tumour, nodes, metastases) staging system (UICC, 1978). The institutional Ethics Committee approved this study, and all subjects provided informed consent.

Estrogen and progesterone receptor binding assays were performed by the dextran-coated-charcoal method (DCC) as previously described (18).

Cell lines and culture conditions. The human breast cancer cell line MCF-7 was obtained from the American Type Culture Collection (ATCC). The cells were cultured at $37^{\circ} \mathrm{C}$ in an atmosphere of $5 \% \mathrm{CO}_{2}, 95 \%$ air in RPMI (phenol red-free) supplemented with $10 \%$ FCS and $1 \%$ penicillin-streptomycin (Gibco). Before the treatments with 17ß-estradiol and 4hydroxytamoxifen, the cells were washed twice with PBS to remove residual serum and grown in media without phenol red, containing $5 \%$ of charcoal-stripped FCS (CS-FCS) for $48 \mathrm{~h}$. After hormone deprivation, the cells were incubated with $17 ß$-estradiol $10 \mathrm{nM}$ for 2, 6 and $24 \mathrm{~h}$ or 4-hydroxytamoxifen $1 \mu \mathrm{M}$ for $24 \mathrm{~h}$. The cells maintained in media without phenol red and 5\% FBS (C) were used as controls.

RNA extraction. Tissue specimens were pulverized under liquid nitrogen using a frozen tissue pulverizer (Termovac). The cells, after the treatments, were washed twice with PBS and harvested. For RNA extraction tissue powder or the harvested cells were homogenized in a solution containing guanidine isothiocyanate and extracted as described by Chomczynski and Sacchi (19). The quality of the RNA samples was determined by $1 \%$ agarose gel electrophoresis and ethidium bromide staining. All RNA samples were treated with DNaseI for $30 \mathrm{~min}$ at $37^{\circ} \mathrm{C}$ to eliminate genomic DNA contamination.

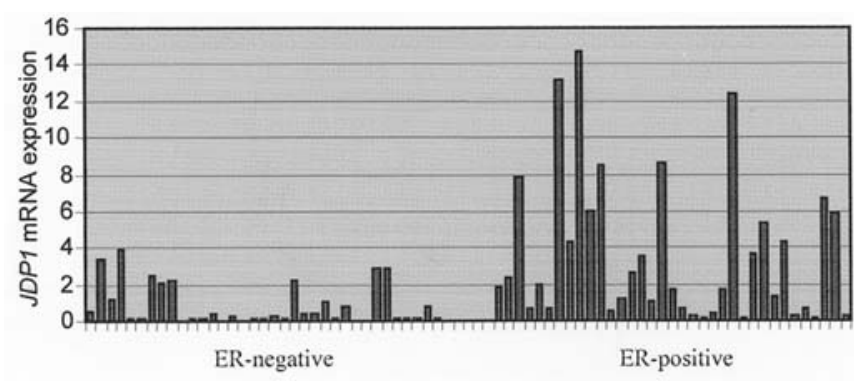

Figure 1. Distribution of the JDP1 mRNA expression in 72 primary breast tumours according to estrogen receptor (ER) status. The relative expression was determined by qPCR, normalized to GAPDH as the reference gene. Height of the bars represents the relative gene expression for individual tumours taking normal breast tissue as calibrator samples. ER-negative, estrogen receptor negative breast tumours; ER-positive, estrogen receptor positive breast tumours.

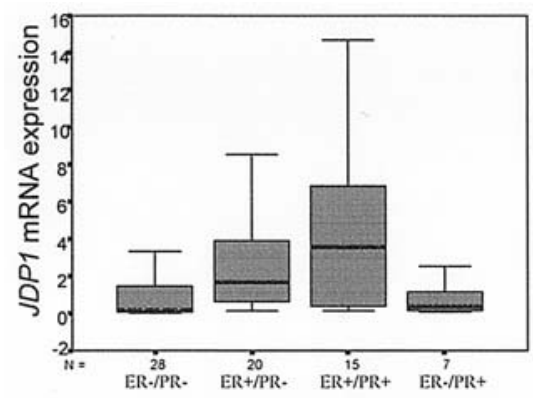

Figure 2. JDP1 mRNA expression in primary breast tumours according to estrogen and progesterone receptor status. The box plot shows the data distributed in relation to median values of JDP1 mRNA expression in 72 primary breast tumours stratified by: ER and PR status $(\mathrm{p}=0.035)$.

Quantitative real-time PCR ( $q P C R)$. qPCR was performed by using the GeneAmp 5700 sequence detector (PE Applied Biosystems). cDNA was generated using the High Capacity cDNA Archive kit (Applied Biosystems). Each cDNA sample was analysed in duplicate. PCR reactions were carried out in a total volume of $50 \mu \mathrm{l}$ according to the manufacturer's instructions for Platimum SYBR Green qPCR SuperMix UDG (Invitrogen). The PCR primers used were as follows: JDP1 (DNAJC12), forward primer 5'-CAGACAAGCATCC TGAAAACCC-3' and reverse primer 5'-TCGCCAGTGG TCATAGCGGGC-3' (this set of primers spans exons 2 and 3 and amplifies a $110 \mathrm{bp}$ fragment common to variants 1 and 2 of the JDPl gene); GAPDH, forward primer 5'-CCTCCAA AATCAAGTGGGGCG-3' and reverse primer 5'-GGGGCA GAGATGATGACCCTT-3'. The relative gene expression was normalized using GAPDH expression as an internal control. The average value of two pools composed of 10 normal tissue samples each served as calibrator sample for the tumours. MCF-7 cells maintained in medium without phenol red and supplemented with 5\% FCS served as calibrator samples for hormone treated cells. The results were expressed as n-fold differences in gene expression of the target gene relative to the expression of the GAPDH gene and calibrator sample. The relative expression was calculated by $2^{-\triangle \Delta \mathrm{CT}}(\mathrm{CT}=$ fluorescence threshold value; $\Delta \mathrm{CT}=\mathrm{CT}$ of the target gene - 


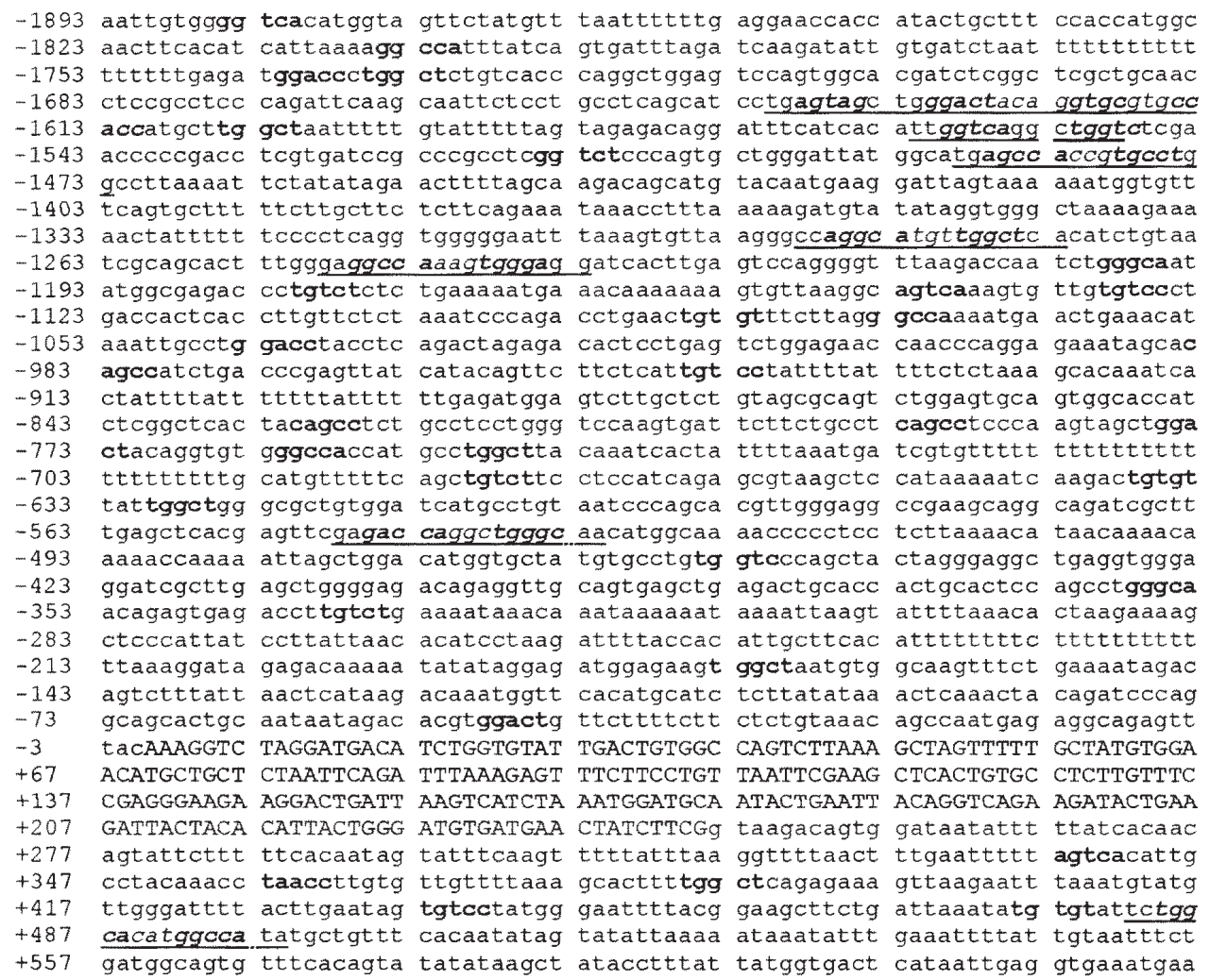

Figure 3. Nucleotide sequence of the JDP1 promoter region. The numbers shown to the left indicate the nucleotide position relative to the transcription start site $(+1)$. The first exon is shown in capitals and the non-coding sequences are represented in small cases. The potential estrogen response elements (EREs) are shown in italic and underlined (the half sites spaced by $3 \mathrm{bp}$ are in bold) and the 1/2 EREs are shown in bold.

$\mathrm{CT}$ of the reference gene $(G A D P H) ; \triangle \triangle \mathrm{CT}=\triangle \mathrm{CT}$ of the target sample - $\triangle \mathrm{CT}$ of the calibrator sample) (20).

Statistical methods. Analyses of statistical significance between the JDP 1 expression levels and the demographic and clinicopathological characteristics of the patients were performed by the Chi-square test and Fisher exact test for frequency data in contingency tables and considered statistically significant at $\mathrm{p}<0.05$. The statistical analysis were performed using SPSS software 10.0 (SPSS Inc., Chicago, IL).

\section{Results}

The pattern of JDP1 (DNAJC12) mRNA expression was determined in a series of 72 primary breast tumours by quantitative real-time PCR reaction. The relative expression of the target gene was determined in $\mathrm{n}$-fold differences relative to the normalized calibrator samples (two pools of normal breast tissue samples). Breast tumours displayed variable patterns of JDPI mRNA expression relative to the normal breast samples. The JDP1 transcripts was normally expressed in 10 tumours (14\%), under-expressed in 36 tumours $(50 \%$; $>2$-fold decrease) and over-expressed in 26 tumours (36\%; $>2$-fold increase).

We correlated the expression levels of the JDP1 transcripts in the breast tumours with the clinicopathological characteristics of the patients, such as, clinical stage, tumour size, nodal status, ER and PR status, overall and disease-free survival. No statistically significant differences were observed, except for the ER status. We found a relationship between the JDP1 mRNA expression levels and the estrogen and progesterone receptor status. The expression levels of the $J D P 1$ transcripts were statistically significantly higher in the group of ER-positive breast tumours compared to the group of ER-negative breast tumours ( $\mathrm{p}=0.02)$ (Fig. 1). In addition, the highest levels of JDP1 mRNA expression were displayed by $\mathrm{ER}^{+} / \mathrm{PR}^{+}$breast tumours $(\mathrm{p}=0.035)($ Fig. 2$)$.

We further evaluated the potential promoter region of the JDP1 gene for the presence of ER-binding sites. The databases at the NCBI (www.ncbi.nlm.nih.gov) and USCS Genome Bioinformatics (www.genome.uscs.edu) were used to annotate the position of the JDPl in the genome and to extract sequences $2 \mathrm{~kb}$ upstream and $2 \mathrm{~kb}$ downstream of the transcription start site for binding-site analyses. The search for EREs and other binding-sites was performed using several publicly available programs (Transfac 6.0, www.gene-regulation.com; and Dragon Genome Explorer, http://research.i2.a-star.edusg/ promoter/). The potential promoter region of the JDP1 contains 7 imperfect palindromic EREs, several widely spaced $1 / 2$ EREs, and binding sites for several transcription factors (Fig. 3).

The promoter region of the JDPl gene showed a high potential to be a target of the ER action. Therefore we further investigate the effect of 17ß-estradiol and tamoxifen on JDP1 mRNA expression in MCF-7 cells, a hormone-responsive breast cancer cell line, using quantitative real-time PCR. For 


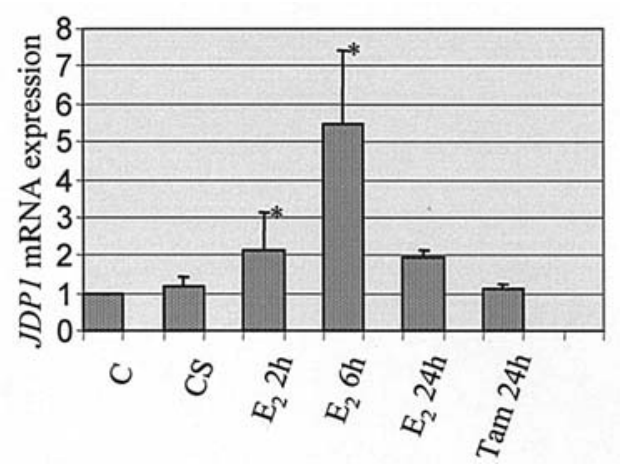

Figure 4. Effect of 17ß-estradiol $\left(\mathrm{E}_{2}\right)$ and Tamoxifen (Tam) on the JDP1 mRNA expression in MCF-7 breast cancer cells. Synchronized MCF-7 cells were in: C, medium supplemented with $5 \%$ fetal calf serum (FCS); CS, medium supplemented with $5 \%$ charcoal-stripped FCS; $\mathrm{E}_{2} 2 \mathrm{~h}$, exposed to $17 ß$-estradiol $(10 \mathrm{nM})$ for $2 \mathrm{~h}$; $\mathrm{E}_{2} 6 \mathrm{~h}$, exposed to 173 -estradiol $(10 \mathrm{nM})$ for $6 \mathrm{~h}$; $\mathrm{E}_{2} 24 \mathrm{~h}$, exposed to $17 \mathrm{~h}$-estradiol $(10 \mathrm{nM})$ for $24 \mathrm{~h}$; Tam $24 \mathrm{~h}$, exposed to Tamoxifen $(1 \mu \mathrm{M})$ for $24 \mathrm{~h}$. Data are expressed as mean $\pm \mathrm{SD}$ of three experiments. ${ }^{*} \mathrm{p}<0.05$ that treatment groups showed higher JDP1 mRNA expression than the control groups.

this purpose synchronized MCF-7 cells were grown in phenol red-free medium containing $5 \%$ of charcoal-stripped serum for at least $48 \mathrm{~h}$ before hormone treatment. After that, the cells were exposed to treatment with 17 B-estradiol for 2,6 and $24 \mathrm{~h}$. After each time period the cells were harvested and total RNA extracted. The relative expression of the JDP1 transcripts was determined by qRT-PCR and the results expressed as means \pm SD for three separate experiments. As shown in Fig. 4, the JDPl transcripts were induced by $17 ß$-estradiol in a time-dependent fashion. MCF-7 cells exposed to $10 \mathrm{nM}$ of 173 -estradiol for $2 \mathrm{~h}$ showed $>2$-fold increased expression of the JDP 1 transcripts when compared to the control cells, not exposed to $17 ß$-estradiol $(2.17 \pm 0.94$ vs. $1.17 \pm 0.23 ; \mathrm{p}=0.016$ ). The maximum induction, 3 - to 7 -fold increased expression, was seen with $6 \mathrm{~h}$ of $10 \mathrm{nM} 173$-estradiol treatment $(5.44 \pm 1.98$ vs $1.17 \pm 0.23 ; \mathrm{p}=0.008)$. MCF-7 cells were also treated with $1 \mu \mathrm{M}$ of tamoxifen for $24 \mathrm{~h}$. Tamoxifen alone did not affect the JDPl expression levels relative to the control cells.

\section{Discussion}

Recently we identified by cDNA microarray a set of differentially expressed genes in breast tumours and showed a direct association between JDP1 mRNA expression and the presence of estrogen receptor in breast tumours (8). In the present study, examining the $J D P l$ expression in a larger series of primary breast tumours, we confirmed our previous results showing that $J D P 1 \mathrm{mRNA}$ expression is direct associated with the ER status in breast tumours. However, no relationship was observed between the expression levels of the JDPI and any other clinicopathological characteristics.

Heat shock proteins are highly conserved and widely expressed chaperones that act in several biological processes preventing the accumulation of improperly folded proteins and promoting proper refold of damaged proteins (21). Members of the high- and low-molecular-weight heat shock proteins, such as Hsp90, Hsp70 and Hsp40 take part in the steroid hormone receptor heterocomplex to assist proper protein folding and activation by hormone binding (5). JDP1 is a member of the DnaJ/Hsp40 family (9). The members of this small-molecular-weight heat shock proteins have been shown to direct interact with the Hsp70 and Hsp90 as a cochaperone protein $(14,21)$. In addition, in yeast, Ydj1/Hsp40 mutants displayed high basal levels of ER activity in the absence of estrogen suggesting that $\mathrm{Ydj} 1 / \mathrm{Hsp} 40$ is important for the receptor regulation by the Hsp90 folding pathway (17). These data suggest that the co-chaperone activity of the DnaJ/Hsp40 in the Hsp90 pathway might also be important for the integrity and functionality of ER in the mammary normal gland and breast tumour tissue. The association observed here between high levels of JDP1 transcripts and the ER positivity may suggest that the JDP1 expression might be a marker of the ER transactivation activity and may have a predictive value for response to hormonal therapy.

Substantial evidence indicates that altered expression of members of the heat shock protein families, such as Hsp90, Hsp70 and Hsp27 play important roles in breast cancer (2225). There is also experimental evidence showing that Hsp90, Hsp70 and Hsp27 are regulated by estrogen via ER in mice uterus, breast cancer cells and in cells from other tissues (26-31). The relationship observed between the JDPI mRNA expression and ER status in the clinical specimens lead us to speculate that the JDP1 could be under the control of ER transcriptional transactivation. The mechanism of estrogen action is complex and depends on several factors, such as the availability of the amount and subtype of the ER, amount and time of the estrogen exposure and presence of different coregulators (32). However, the genomic effects of the estrogen is thought to be mediated by the interaction between the estrogen receptor with specific DNA binding sites named estrogen response elements (EREs) or by the interaction with other transcription factors, such as AP1 and SP1 $(3,33,34)$. We identified and analysed the promoter region 5 ' up-stream of the JDPl gene for the presence of potential ERE binding sites. We were able to identify seven imperfect palindromic EREs and several widely spaced $1 / 2$ EREs in the potential promoter region of the JDPl gene, suggesting that it might be transcriptionally regulated by estrogen. So far, this was confirmed by preliminary experiments in MCF-7 breast cancer cells upon 17ß-estradiol treatments. In MCF-7 cells exposed to $10 \mathrm{nM}$ of $17 ß$-estradiol the JDPl transcripts were up-regulated in a time-dependent fashion. The levels of the Hsp90 transcripts are also regulated by $17 ß$-estradiol in a time-dependent fashion in uterus of ovarectomized mice, the Hsp90 mRNA levels reach a maximum in 2-6 $\mathrm{h}$ and decline to control baseline value after $24 \mathrm{~h}$ after estradiol administration $(26,35)$. Although further functional studies are required to determine the role and possible cooperativity of the potential EREs observed in the promoter regions of the JDPl gene to confer estrogen responsiveness, this is the first report identifying the $J D P 1$ as a novel estrogen target gene. It has been proposed that some members of the DnaJ/Hsp40 proteins, which interact and cooperate with $\mathrm{Hsp} 70$ as a co-chaperone are required to assist the assembly and maintenance of a functional aporeceptor complex (36). The estrogen induction of different heat shock proteins, such as Hsp90, Hsp70 and also the JDPl (DnaJ/Hsp40) that are components of the 
receptor heterocomplex may work as a positive feedback for the appropriate supply of proteins required to maintain proper receptor folding and signal transduction.

\section{Acknowlegdments}

Grant number 03/13170-0 from Fundação de Amparo à Pesquisa do Estado de São Paulo (FAPESP) supported this work. This work was also supported in part by the Conselho Nacional de Pesquisa (CNPq).

\section{References}

1. Kelsey JL, Gammon MD and John EM: Reproductive factors and breast cancer. Epidemiol Rev 15: 36-47, 1993.

2. Persson I: Estrogens in the causation of breast, endometrial and ovarian cancers - evidence and hypotheses from epidemiological findings. J Steroid Biochem Mol Biol 74: 357-364, 2000.

3. Hall MJ, Couse JF and Korach KS: The multifaceted mechanisms of estradiol and estrogen receptor signaling. J Biol Chem 276: 36869-36872, 2001.

4. Nilsson S, Makela S, Treuter E, Tujague M, Thomsen J, Andersson G, Enmark E, Pettersson K, Warner M and Gustafsson JA: Mechanisms of estrogen action. Physiol Rev 81: 1535-1565, 2001.

5. Pratt WB and Toft DO: Steroid receptor interactions with heat shock protein and immunophilin chaperones. Endocr Rev 18: 306-360, 1997.

6. Pratt WB: The hsp90-based chaperone system: involvement in signal transduction from a variety of hormone and growth factor receptors. Proc Soc Exp Biol Med 217: 420-434, 1998.

7. Fliss AE, Benzeno S, Rao J and Caplan AJ: Control of estrogen receptor ligand binding by Hsp90. J Steroid Biochem Mol Biol 72: 223-230, 2000.

8. Nagai MA, Da Ros N, Neto MM, De Faria Junior SR, Brentani MM, Hirata R Jr and Neves EJ: Gene expression profiles in breast tumors regarding the presence or absence of estrogen and progesterone receptors. Int J Cancer 111: 892-899, 2004.

9. Lee J, Hahn Y, Yun JH, Mita K and Chung JH: Characterization of JDP genes, an evolutionarily conserved J domain-only protein family, from human and moths. Biochim Biophys Acta 1491: 355-363, 2000.

10. Cyr DM, Langer T and Douglas MG: Dnaj-like proteins: molecular chaperones and specific regulators of hsp70. Trends Biochem Sci 19: 176-181, 1994.

11. Kelley WL: The J-domain family and the recruitment of chaperone power. Trends Biochem Sci 23: 222-227, 1998.

12. Cyr DM and Douglas MG: Differential regulation of $\mathrm{Hsp} 70$ subfamilies by the eukaryotic DnaJ homologue YDJ1. J Biol Chem 269: 9798-9804, 1994.

13. Pellecchia M, Szyperski T, Wall D, Georgopoulos C and Wuthrich K: NMR structure of the J-domain and the Gly/Pherich region of the Escherichia coli DnaJ chaperone. J Mol Biol 260: 236-250, 1996.

14. Kelley WL: Molecular chaperones: how J domains turn on Hsp70s. Curr Biol 9: R305-R308, 1999.

15. Kimura Y, Yahara I and Lindquist S: Role of the protein chaperone YDJ1 in establishing Hsp90-mediated signal transduction pathways. Science 268: 1362-1365, 1995.

16. Schnaider T, Soti C, Cheetham ME, Miyata Y, Yahara I and Csermely P: Interaction of the human dnaj homologue, hsj1b with the $90 \mathrm{kDa}$ heat shock protein, hsp90. Life Sci 67: 1455-1465, 2000.

17. Johnson JL and Craig EA: A role for the hsp40 ydj1 in repression of basal steroid receptor activity in yeast. Mol Cell Biol 20: 3027-3036, 2000.
18. Brentani MM, Nagai MA, Fujyama CT and Góes JCS: Steroid receptors in a group of brazilian breast cancer patients. J Surg Oncol 18: 431-439, 1981.

19. Chomczynski P and Sacchi N: Single-step method of RNA isolation by acid guanidinium thiocyanate-phenol-chloroform extraction. Anal Biochem 162: 156-159, 1987.

20. Giulietti A, Overbergh L, Valckx D, Decallonne B, Bouillon R and Mathieu C: An overview of real-time quantitative PCR: applications to quantify cytokine gene expression. Methods 25: 386-401, 2001.

21. Fink AL: Chaperone-mediated protein folding. Physiol Rev 79: 425-449, 1999.

22. Jameel A, Skilton RA, Campbell TA, Chander SK, Coombes RC and Luqmani YA: Clinical and biological significance of HSP89 alpha in human breast cancer. Int J Cancer 50: 409-415, 1992.

23. Vargas-Roig LM, Gago FE, Tello O, Aznar JC and Ciocca DR: Heat shock protein expression and drug resistance in breast cancer patients treated with induction chemotherapy. Int $\mathbf{J}$ Cancer 79: 468-475, 1998.

24. Thanner F, Sutterlin MW, Kapp M, Rieger L, Kristen P, Dietl J, Gassel AM and Muller T: Heat-shock protein 70 as a prognostic marker in node-negative breast cancer. Anticancer Res 23: 1057-1062, 2003.

25. O'Neill PA, Shaaban AM, West CR, Dodson A, Jarvis C, Moore P, Davies MP, Sibson DR and Foster CS: Increased risk of malignant progression in benign proliferating breast lesions defined by expression of heat shock protein 27. Br J Cancer 90: 182-188, 2004.

26. Shyamala G, Gauthier Y, Moore SK, Catelli MG and Ullrich SJ: Estrogenic regulation of murine uterine 90-kilodalton heat shock protein gene expression. Mol Cell Biol 9: 3567-3570, 1989.

27. Charpentier AH, Bednarek AK, Daniel RL, Hawkins KA, Laflin KJ, Gaddis S, MacLeod MC and Aldaz CM: Effects of estrogen on global gene expression: identification of novel targets of estrogen action. Cancer Res 60: 5977-5983, 2000.

28. Porter W, Wang F, Duan R, Qin C, Castro-Rivera E, Kim K and Safe S: Transcriptional activation of heat shock protein 27 gene expression by 17 beta-estradiol and modulation by antiestrogens and aryl hydrocarbon receptor agonists. J Mol Endocrinol 26: 31-42, 2001.

29. Papaconstantinou AD, Fisher BR, Umbreit TH, Goering PL, Lappas NT and Brown KM: Effects of beta-estradiol and bisphenol A on heat shock protein levels and localization in the mouse uterus are antagonized by the antiestrogen ICI 182,780. Toxicol Sci 63: 173-180, 2001.

30. Zhang Y, Champagne N, Beitel LK, Goodyer CG, Trifiro M and Le Blanc A: Estrogen and androgen protection of human neurons against intracellular amyloid beta1-42 toxicity through heat shock protein 70. J Neurosci 24: 5315-5321, 2004.

31. Hamilton KL, Gupta S and Knowlton AA: Estrogen and regulation of heat shock protein expression in female cardiomyocytes: cross-talk with NF kappa B signaling. J Mol Cell Cardiol 36: 577-584, 2004.

32. McDonnell DP and Norris JD: Connections and regulation of the human estrogen receptor. Science 296: 1642-1644, 2002.

33. Klinge CM: Estrogen receptor interaction with estrogen response elements. Nucleic Acids Res 29: 2905-2919, 2001.

34. O'Lone R, Frith MC, Karlsson EK and Hansen U: Genomic targets of nuclear estrogen receptors. Mol Endocrinol 18: 1859-1875, 2004.

35. Papaconstantinou AD, Goering PL, Umbreit TH and Brown KM: Regulation of uterine hsp90alpha, hsp72 and HSF-1 transcription in $\mathrm{B} 6 \mathrm{C} 3 \mathrm{~F} 1$ mice by beta-estradiol and bisphenol A: involvement of the estrogen receptor and protein kinase C. Toxicol Lett 144: 257-270, 2003.

36. Bohen SP, Kralli A and Yamamoto KR: Hold 'em and fold' em: chaperones and signal transduction. Science 268: 1303-1304, 1995. 